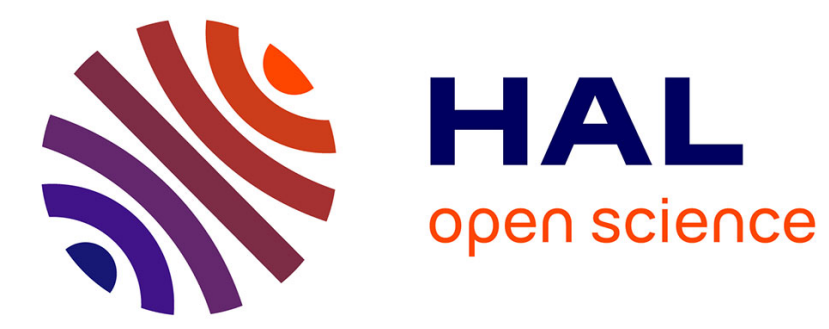

\title{
The sex-linked dwarf gene in the broiler chicken industry
}

\section{To cite this version:}

The sex-linked dwarf gene in the broiler chicken industry. WPSA Journal, 1984, 40 (1), pp.10-17. hal-02716926

\section{HAL Id: hal-02716926 \\ https://hal.inrae.fr/hal-02716926}

Submitted on 1 Jun 2020

HAL is a multi-disciplinary open access archive for the deposit and dissemination of scientific research documents, whether they are published or not. The documents may come from teaching and research institutions in France or abroad, or from public or private research centers.
L'archive ouverte pluridisciplinaire HAL, est destinée au dépôt et à la diffusion de documents scientifiques de niveau recherche, publiés ou non, émanant des établissements d'enseignement et de recherche français ou étrangers, des laboratoires publics ou privés. 


\title{
The sex-linked dwarf gene in the broiler chicken industry
}

\author{
P. MERAT
}

Laboratoire de Génétique Factorielle, I.N.R.A.-C.N.R.Z., F 78350 JOUY-en-JOSAS (FRANCE)

\section{Introduction}

The main aim in the selection of broiler chickens for several decades has been to obtain a faster growth rate. This leads to increasingly earlier slaughter and thus to progressively higher feeding efficiency, but there is also an unavoidable disadvantage: the correlatively greater size of breeders, particularly females, results in high maintenance requirements, increased cost price of chicks and mediocre performance as to reproduction, egg production and hatching rate (Japp, 1968a). These factors are responsible for the interest that has developed in the potential use of the smaller breeding hens, which can be obtained with the $\mathrm{d} w$ gene, without a marked reduction in chicken growth.

The dw mutation has been described by Hutt (1959). The main effect of this sexlinked recessive gene is a reduction in the body weight, about $30 \%$ in adult hens. Several reviews have been devoted to the effects of this gene (Polkinghorne, 1973; Guillaume, 1976; Ricard, 1976). Only the last of these reviews concerns the specific problem of the use of the $\mathrm{dw}$ gene in broiler production and it thus seemed useful to review the subject again. The present paper is not intended to be an exhaustive survey of the literature on the sex-linked dwarf gene.

\section{The Scheme of Utilization of the dw Gene for Broiler Production}

According to the classical scheme, the chick to be used is a terminal cross between a broiler male and a broiler female. The broiler male is a cross of two strains, A and B; the broiler female is the cross of two other strains, $C$ and $D$. The broiler must have the normal phenotype $\left(\mathrm{Dw}^{+}\right)$. The broiler male should thus have the $\mathrm{Dw}^{+} \mathrm{Dw}^{+}$genotype, i.e. the two strains, A and B, are homozygous for the allele Dw. If the broiler female is dwarf, the maintenance cost of breeder flocks will be greatly decreased. This idea was perceived in France by Cochez (1962) and developed by Jaap (1969) and other authors such as Van Middelkoop (1973), Polkinghorne (1973), Hartmann (1978). For the female of the $C \times D$ cross to be dwarf, the $C$ line must be homozygous for the $d w$ gene, strain $\mathrm{D}$ being preferably normal so that the brothers of the broiler breeder will be of normal size and can be sold as broilers.

The present paper attempts to group together published results which permit the advantages of the dw gene to be assessed at different levels of broiler production: egg production, reproduction in the maternal line and broiler performance.

\section{Performance of Dwarf Breeders}

Growth curve: Ricard (1976) reviewed earlier data on the live weight of dwarf breeders. The reduction in weight compared with $\mathrm{Dw}^{+}$females of comparable origin is about one-third; in data given by the author, it is between 31 and $33 \%$, depending on age. The rate of reduction may vary according to the genetic context; according to Reddy and Siegel (1977) and Cherry and Siegel (1978) this rate is less in a line selected for high weight, than in a line selected for low body weight.

Many authors (review by Guillaume, 1976) have shown that the dwarf chicken is fatter than the normal chicken. On the contrary, Merat and Ricard (1974) observed that 
this was no longer the case in adult hens, perhaps due to the output of lipids for egg formation which is relatively higher in dwarf hens as related to their body-size. This is confirmed by other data (Ricard, 1976).

Egg production: Whatever the population into which the dw gene is introduced, it delays the age at first egg generally by 1 to 2 weeks. This is clear from the review by Guillaume (1976). On the other hand, the ef fect of the dwarf gene on the number of eggs is not the same in light and heavy-weight strains. This point will be discussed on the basis of published results on broiler-type strains.

The dw allele in such strains is not accompanied by a reduction in the number of eggs, according to Prod'homme and Merat (1969), Sherwood (1971), Ricard and Cochez (1972), Chambers et al. (1974), Reddy et al. (1974), Strain and Piloski (1975), Ricard (1976), Reddy and Siegel (1977), Cherry and Siegel (1978), Hartmann (1978) and Marks (1981). Most of the authors cited noted a slight difference in favour of dwarf hens. Two publications (Sherwood, 1971; Ricard and Cochez, 1972) respectively for egg number and hen-day production, showed a significant advantage associated with the dwarf gene.

Feed conversion for egg production: Due to the fact that body size at all ages is decreased by the dwarf gene and that the number of eggs is not unfavourably affected, this gene should improve feed conversion for egg production (whether or not intake during growth is included). This point has been stressed by Guillaume (1976) and Ricard (1976) in their respective reviews and has been confirmed by several authors: for the ratio of feed ingested to weight of eggs laid, dwarf breeders have an advantage of 20 and $15 \%$, respectively, in two tests carried out by Prod'homme and Merat (1969), of 36\% (Sherwood, 1971) and of 18\% (Yamada et al., 1972); using one dozen eggs as a basis, the advantage observed was $36 \%$ for Chambers et al. (1974) and $21 \%$ for Strain and Piloski (1975). In field data collected in the USA by Weaver (1974), feed cost was expressed in lb. per chick produced; it was 0.52 and 0.77 for dwarf and normal breeders, respectively, or a gain of $33 \%$ with the dwarfs.

The magnitude (at least $20 \%$ ) of saving on food intake (during growth and egg production) for the same weight of eggs produced is also indicated in instruction books for the use of the dwarf breeder in France.

Mortality: Not only is mortality no higher with the $\mathrm{dw}$ gene, but some authors suggest an improvement of viability. Yamada et al. (1972) report this for the egg production phase. The data of Ricard (1976) led to the same conclusion. Moreover, and although not only broiler strains are concerned, resistance to Marek's disease has been found to be higher in dwarf chickens or layers than in their normal-sized homologues: Rapp (1970) in one out of 2 tests, Meurier and Merat (1972), Ricard (1976) and Hartmann (1978). Furthermore, Haas et al. (1975) found no difference between dwarf and normal genotypes as to susceptibility to various pathogenic agents such as Salmonella pullorum, E. coli, mycoplasmosis and coccidiosis. Stephens and Dreyfuss (1978) found no difference concerning the response to vaccination against Newcastle disease. Rapp (1970) suggested that dw hens have fewer laying accidents.

Finally, studies on immune response comparing dwarf and normal birds (e.g. Reddy et al., 1975; Mauldin et al., 1978; Marsteller et al., 1980 and Mauldin et al., 1981) showed that in a heavy strain this response is not lower, and may even be higher in dwarf birds compared to normals.

Percentage of abnormal (soft-shelled or shell-less, double-yolked) and broken eggs: Fewer double-yolked eggs are found in dwarf hens according to Mohammadian (1969) and Japp and Mohammadian (1969). This is an advantage in a broiler strain because Japp and Muir (1968) and Jaap (1968a) showed that in this case there was an 
excessive number of fast-growing follicles compared to laying strains which caused an excess of defective eggs. This effect of the $\mathrm{dw}$ gene on the percentage of abnormal eggs has been confirmed by Kuit and Van Middelkoop (1972), and Van Middelkoop (1973), Reddy et al. (1974) and Reddy and Siegel (1977), the last authors studying two lines selected for high and low body weight, respectively.

By comparison, in layer strains, the dw gene also reduces the proportion of doubleyolked eggs (Banerjee et al., 1982) and of soft-shelled eggs (Silber and Merat, 1974) but decreases egg production.

Moreover, it has been demonstrated by Raap (1970), Ricard and Cochez (1972), Silber and Merat (1974b) and others, that the dw gene reduces the percentage of broken eggs in laying batteries. Only Ricard and Cochez studied a female broiler-type population. However, since the causes for the reduction in the number of broken eggs by dwarfism are probably mechanical (lighter-weight hens putting less pressure on the cage bottom; height of fall of egg being reduced at oviposition), they should have an effect whatever the body size of the population in question, and probably would have even more effect in a heavy-weight strain. This decrease (by about one-half in data from Silber and Merat, 1974b) in the percentage of eggs broken in the battery might be important, if artificial insemination of broiler strains became a general procedure.

Fertility and hatching rate of terminal cross; number of chicks per breeder: Some authors report hatching rates (ratio of chicks hatched to eggs incubated) compared for normal $\left(\mathrm{Dw}^{+}\right)$and dwarf (dw) breeder females mated to similar $\mathrm{Dw}^{+} \mathrm{Dw}^{+}$males (Sherwood, 1971; Ricard and Cochez, 1972; Chambers et al., 1974; Weaver et al., 1974; Ricard, 1976 and Proudfoot et al., 1982). In the first case, the significance was not given and in the others the difference between maternal genotypes was not significant. In Sherwood's data, normal hens had a slight advantage, Proudfoot et al. found no difference. The results of Ricard and Cochez, Chambers et al., Weaver et al., and Ricard showed that the hatching rate of dwarf mothers was higher than that of normal mothers.

Fertility rate does not seem to differ consistently in favour of one or the other maternal genotype: it is about equal Chambers et al. (1974), slightly better and slightly poorer for dwarf breeder hens according to Ricard and Cochez (1972) and Proudfoot (1982), respectively. According to Ricard (1976), in the mating of $\mathrm{Dw}^{+} \mathrm{Dw}^{+}$males with mixed $\mathrm{Dw}^{+}$and dwarf females in pedigree pens, fertility is sometimes better and sometimes poorer for the latter. This author believes that for fertility to be satisfactory in the terminal cross in mass reproduction in floor pens, the number of cockerels must be decreased compared to that in the classical cross, the optimum being one male for 15 to 18 hens.

The attributes discussed here (egg production, egg quality, fertility, hatching rate) suggest that the number of chicks produced per dwarf breeder is at least equal to or higher than that obtained with normal breeders. This has been demonstrated by Sherwood (1971), Chambers et al. (1974), Weaver (1974) who found the following number of chicks for normal hens and comparable dwarf hens, respectively: 93 vs 107, 65.1 vs $66.1,117.1$ vs 123.5 .

Other advantages of the dw gene: Another advantage of the dwarf breeder is that it occupies less space in the hen-house for the same chick production, thus permitting a 40 to $50 \%$ higher stocking density (Anonymous, 1970). The dwarf breeder also has a lower volume of faeces for the same egg production (e.g. Van Middelkoop and Zegwaard, 1973). 


\section{The Optimal Environment for Dwarf Breeders}

Guillaume (1976) reviewed the feed formula and rationing of the dwarf breeder. The main points are: broiler-type dwarf hens can be restricted with no disadvantage during growth, thus reducing their adult size while egg production remains unchanged (Leclercq, Guillaume and Blum, 1970 and Leclercq and Blum, 1972). In the U.S.A., several research workers such as Hazen and Waldroup (1971), Waldroup and Hazen $(1975,1976)$ and Cherry and Siegel $(1979,1981)$ have reached analogous conclusions. The only precaution required is that the protein intake of the young chickens should not be limited between 0 and 6 weeks of age, otherwise egg production is lowered (Leclercq and Blum, 1973 and Leclercq and Blum, 1975). It is also recommended that sulphur amino acids should be at an adequate level in layer feeds in order to increase egg weight, chick weight and even chick growth, especially at the beginning of the season of egg production (Guillaume, 1973b; Larbier and Blum, 1975 and Blum et al., 1979). Otherwise, the dwarf breeder needs no special diet and its energy requirements are particularly low.

Several authors (Merat et al., 1974 and Horst and Petersen, 1978, 1979) studying layer-type hens of light or medium weight, have suggested that dwarf hens have better heat tolerance which might be an advantage for egg production at high ambient temperatures. It would be interesting to check this on a broiler breeding flock.

\section{Characteristics of Chickens from Dwarf Hens}

It is essential to know if the $d w$ gene of the mother affects progeny growth performance due to the fact that the genotype of the male chick is heterozygous $\left(\mathrm{Dw}^{+} \mathrm{dw}\right)$ or that the mean weight of the eggs of the dam is reduced.

Weight gain of chickens: Table 1 summarizes published comparisons of the growth of broilers of both sexes from normal and dwarf dams. Each result is expressed by its deviation (plus or minus) in percentage from the average body weight of the progeny of normal mothers; in general, and if not otherwise indicated, weight at 8 weeks has been used. The dwarf and normal dams compared are often from heterozygous $\left(\mathrm{Dw}^{+} \mathrm{dw}\right)$ sires so that the rest of the genome is as comparable as possible. In other cases (Sherwood, 1971; Timmons, 1971; Khan and Jaap, 1974; Weaver, 1974; Proudfoot et al., 1982 and Whiting and Pesti, 1982), $\mathrm{Dw}^{+}$and $\mathrm{dw}$ hens from two distinct lines have been compared.

The significance of the differences is not given in each case since most are not significant. However, it appears that in most cases, the male progeny showed slightly depressed growth when the mother was dwarf. The extreme deviations range from $+1 \%$ (no unfavourable effect) to almost $-7 \%$, but the majority fall between -2 and $-4 \%$ (average between 2 and $3 \%$ ). If there is a depressive effect in females when the mother has a dw genotype, it is still lower and not constant (mean deviations +2.8 to $-5.8 \%$; on average, between 0 and $-1 \%$ ).

If there is a true weak effect in the females, it can be attributed only to reduced egg weight when the dam is dwarf; it is known that egg weight affects growth during the first weeks of age (Bray and Iton, 1962; Powell and Bownan, 1964; Merritt and Gowe, 1965 and Morris et al., 1968).

On the other hand, the slightly retarded growth in males can be interpreted as a result of their genotype being $\mathrm{Dw}^{+} \mathrm{dw}$ instead of $\mathrm{Dw}{ }^{+} \mathrm{Dw}{ }^{+}$when the mother carries the dw gene. Thus, dwarf breeders would necessitate an extra effort to select on chicken weight. However, the sexual morphism of chickens is reduced, which can be beneficial when the sexes are not raised separately. 


\section{TABLE 1: Comparison of normal chickens from $\mathrm{Dw}^{+}$or $\mathrm{dw}$ dams}

Reference

Jaap (1968a)

Mohammadian (1970)

Sherwood (1971)

Timmons (1971)

Mohammadian and

Jaap (1972)

Ricard (1972)

Yamada et al. (1972)

Weaver (1974)

Whiting and Pesti (1982)

Chambers et al. (1974)
Khan and Jaap (1974)
Ricard and Conan (1974)
Strains and Piloski (197)
Ricard (1976)
Proudfoot et al. (1982)
Stewart and Washburn
(1982)

\begin{abstract}
Mean weight of progeny of dw dams as per cent deviation from means of progeny from $\mathrm{DW}+$ dams (computed from authors' results)

males females
\end{abstract}

$\begin{array}{lc}-2.5 \text { to }-5 \% & \text { no differ } \\ -2.9 & +2.8 \\ - & - \\ & - \\ -2.5 & +1.4 \\ -3.3 & +0.7 \\ \text { (No significant difference) }\end{array}$

\section{Food conversion of broilers}

$\begin{array}{lll}(1 & -7.4 & -5.8 \\ (2 & -5.7 & -1.8 \\ (1-3.9 & -1.8 \\ (2-7.9 & -5.2 \\ -1.4 & -0.8 \\ (1 \quad-2.0 & -0.6 \\ (2-3.4 & +0.5 \\ +1.0 & 0.0 \\ -2.1 & -1.7\end{array}$

(not given-lower weight for male progeny of dw dams) $\begin{array}{ll}-2.8 & -1.7\end{array}$
Observations

( -5.3 sexes grouped)

$(+4.6$ sexes grouped; data

collected over several locations)

(Trial 1: no difference, sexes grouped)

(Trial 2: +6.6 , sexes grouped, but progeny of dw dams

slaughtered 2-3 days later.

(1-age of dams: 29 weeks

(2-age of dams: 49 weeks

(1-comparison in lines selected

on body weight

(2-comparison in lines selected on egg weight

( 1 -all breeder dams in floor pens

(2-comparison with dw dams in cages

7 week weight

7 week weight

It is likely a priori that if the food conversion of broilers is affected by the maternal genotype, it would be less influenced (in percentage) than weight. In fact, results published on this point have shown either a difference close to zero between broilers from $\mathrm{Dw}^{+}$and dw mothers or a small non-significant difference. Among the former are Yamada et al. (1972), Ricard and Conan (1974), Proudfoot et al. (1982) and Stewart $e$ t al. (1982). Sherwood (1971) observed a food conversion for growth that was slightly poorer with dwarf mothers; Strain and Piloski (1975) reported the same tendency only when the mothers were kept in cages. Timmons (1971) in group test results in the U.S.A. assessed the total food conversion of broilers from dw mothers at 2.076 vs 2.040 for broilers from $\mathrm{Dw}^{+}$mothers in comparable conditions. On the other hand, Weaver (1974) in two different experiments found a food conversion of 1.90 and 1.87 (experiment 1) and 1.89 and 1.92 (experiment 2 ) for broilers from normal and dwarf mothers, respectively, thus showing about equal value on the whole.

Broiler body composition: The body composition is not affected by incorporation of the dwarf gene in the maternal strain; this includes slaughter yield (Ricard, 1972; Ricard and Conan, 1974; Ricard, 1976) and the meat/bone ratio (Ricard, 1972). Ricard (1976) found a slight increase for the percentage of fat. Stewart et al. (1982) observed no difference in this regard or for total lipids. It should be noted that such effects could occur essentially in male progeny. 


\section{Reproduction of the Dwarf Strain: Fertility of Dwarf Males}

A related problem is the reproduction of the female broiler dwarf strain and the value of the dwarf male as a breeder. Studies have been carried out by De Reviers and Petitjean (1973), Petitjean and De Reviers (1973), Ricard (1976) and Blokowlak et al. (1980). A comparison between dwarf and normal cocks shows a delay in sexual maturity of some 10 days and a decrease in the amount of sperm collected artificially and in its concentration for the former but, on the other hand, a better motility index (Ricard, 1976) finds the fertilization rate with natural mating very good with dw hens; with $\mathrm{Dw}^{+}$ hens this author also found that fertility results are good in the crosses used.

\section{Possible Effects of the dw Gene on the Result of Interstrain Selection on Growth}

Several authors have wondered if the efficiency of selection on growth rate within a dwarf strain was modified compared to a similar normal population. The important factor is to consider the genetic gain obtained in the final product. In this respect, no clear tendency is evident. A partial indication mentioned by Ricard and Cochez (1973) was a greater phenotypic variance and heritability of body weight at 8 weeks in dw broilers than in normal ones segregated in the same population. Khan (1973), then Khan et al. (1975) selected for 2 generations on weight at 8 weeks in two sublines, one dwarf and the other normal-sized, and then compared the cross of these lines with a male $\mathrm{Dw}^{+}$ $\mathrm{Dw}^{+}$strain. The gain noted from the dwarf strain seemed to be lower after a generation of selection, but this was almost annulled in the following generation. According to Polkinghorne and Harvey (1978), heritability of body weight at 50 days is the same in dwarf and normal birds, but the genetic correlation between the performances of dwarf and normal progeny from the same families is less than 1, suggesting that it would be better to select the dams on the performance of their progeny rather than on their own growth.

Finally, according to Marks (1981), a comparison of three selection generations in a normal and a dwarf line showed about the same response for progeny growth obtained by crossing with a normal-sized male line. The results suggested a slightly lower heritability in the dwarf line, but this was compensated by greater selection intensity.

\section{Conclusions}

The preceding data suggest in all a positive gain in the use of the sex-linked dw gene for dwarfism in order to reduce the size of female broiler strains. Some authors discuss this at the economic level (in the U.S.A.: Anonymous, 1972; Weaver, 1974; Strain and Piloski, 1975; in France: Persil, 1972). It is difficult to present an economic balance of general significance because it depends on changing conjectures. First, it must be noted that the balance is only favourable if the whole production cycle of the broiler is considered and not only the rearing stage. The main evidence for and against may be summarized as follows:

The only obvious disadvantages might be depressed growth, but mainly or only in male broilers; this decrease amounts to about 2 to $4 \%$ or 1 to $2 \%$ on the mean of the two sexes. On the other hand, there seem to be no unfavourable effects on food conversion or body composition.

There is also a possibility of mating difficulties between the large cockerels and smaller hens which might indicate artificial insemination if maximum fertility and mimimum damage to the hens are to be achieved.

The main advantages are:

the feeding of the breeder female is at least $20 \%$ more economical both during rearing and egg production; there is about a $40 \%$ saving on density in the breeding house; 
the number of chicks per hen is higher (about $+4 \%$ ), egg production being at least equal to that of normal breeders, with fewer abnormal eggs and fewer eggs broken or cracked in battery;

in general, the viability of female broiler breeders is better.

These advantages should be maximized by restricted feeding of the breeder female, preferably with additional methionine in the feed during laying, Finally, Weaver (1974) suggests using dwarf breeders to produce broilers slaughtered at relatively low weight ( 2 to $3 \mathrm{lb}$.), the economic advantage gained on 1-day chicks then having the greatest relative importance on the total cost price of the broiler.

Problems remaining to be solved include more detailed research on conditions optimizing the use of the dwarf breeder and a more exact evaluation of some effects associated with the dwarf gene, which are weak but economically important; these include determining if, or in which conditions, the effect on broiler feed conversion is reduced, but existent, or whether it is zero.

\section{Summary}

The potential use of the sex-linked dwarf gene in the broiler industry is discussed from published results. It is suggested that the gain from such utilization is positive if the whole of the cycle of breeding and broiler raising is considered. The factors contributing to the benefits to be expected from the use of dwarf breeder females and research remaining to be carried out are discussed. Some possible disadvantages are mentioned.

\section{Résumé}

\section{LE GÈNE DE NANISME LIÉ AU SEXE DANS L'INDUSTRIE DU POULET DE CHAIR (P. Merat)}

L'utilisation potentielle du gène de nanisme lié au sexe dans l'industrie du poulet de chair est discutée à partir des résultats de la littérature. Il est suggéré que le bilan de cette utilisation est positif à condition de considérer l'ensemble du cycle de reproduction et d'élevage des jeunes. Les facteurs pouvant rendre maximum le bénéfice tiré de l'emploi de reproductrices naines et les problèmes nécessitant des recherches ultérieures sont discutés.

\section{Zusammenfassung}

\section{DAS GESCHLECHTSGEBUNDENE VERZWERGUNGSGEN IN DER MASTGEFLÜGEL- INDUSTRIE \\ (Merat)}

Die Möglichkeiten zur Anwendung des geschlechtgebundenen Verzwergungsgens in der Mastgeflügelerzeugung werden anhand veröffentlichter Ergebnisse diskutiert. Es wird darauf hingewiesen, daß der Nutzen aus der Anwendung dieses Erbfaktors positiv ist, wenn der gesamte Zyklus der Vermehrung und Erzeugung von Broilern betrachtet wird. Die Faktoren, die zu den erwarteten Vorteilen bei Verwendung von verzwergten weiblichen Broilereltern beitragen und die noch durch Forschung zu klärenden Fragen werden diskutiert. Außerdem wird auf einige mögliche Nachteile hingewiesen.

PE3

СЦЕПЛЕННЫЙ С ПОЛОМ ГЕН КАРЛИКОВОСТИ В ПРОИЗВОДСТВЕ БРОЙJЕРНЫХ ШЫПЛЯТ

/П.MEPAP/

На основе опубликованных результатов обсуждается потенциальное использование сцепленного с полом гена карликовости в производстве бройлеров. Предполагается, что данная практика приносит пользу, если учитывается весь цикл селекции и выращивания бройлеров. Рассматриваются факторы, способствующие получению ожидаемых ныгод от использования карликовых племенных курочек, а также от научных исследований, которые еще осталось провести.

Также упоминаются некоторые возможные и отрицательные стороны. 


\section{References}

ANONYMOUS, (1974). Midget-type meat breeders and normal chickens compared. Poultry Digest, 1974, p. 306

BANERJEE, A. K., BORDAS, A., MERAT, P. (1982). Sex-linked dwarf gene (dw) in While Leghorn laying hens under normal or hol temperature. Ann. Genet. Sel. anim 14: 135 .

BI OKOWLAK, C.C., SIEGEL, P. B., VANKREY, H. P. (1980). Sexual behaviour of dwarf and normal genotypes in divergent growth lines of chicken. Applied Animal EIhology 6: 189

BLUM, J. C., SIMON, J., LARBIER, M. (1979). Importance du milieu el des conditions nutritionnelles pendant les premiers stades de la vie sur le développement statural et fonctionnel des oiscaux. Annual Biological Animal Biochemistry Biophys 19(1): 303.

BRAY, D. F., IRON, E. L. (1962). The ef fect of egg weight on strain differences in embryonic and post-embryonic growth in the domestic fowl. British Poultry Science 3: 175

BULLERMANN-HENDL. A. (1981). (Effect of the dwarfing gene (dw) on characters of shell stability and shell structure in light White Leghorn hens in moderate and high environmental temperatures). Thesis, Freie Universitat Berlin. (allem.)

CHAMBERS, J. R., SMITH, A. D., McMILLAN, I., FRLARS, G. W. (1974). Comparison of normal and dwarf broiler breeder hens. Poultry Science 53: 864

CHERRY, J. A., SIEGEL,P.B.(1978). Dwarfism in diverse genetic backgrounds: Diet-egg production relationships. Poultry Science 57: 325 .

CHERRY, J. A., SIEGEL, P. B. (1979). Dwarfism in diverse genetic backgrounds: 3 . Effect of dietary protein. Poultry Science 58: 991.

CHERRY, J. A., SIEGEL, P. B. (1981). Dwarfism in diverse genetic backgrounds: 4. Effects of dietary energy. Poultry Science 60: 683 COCHEZ, L. P. (1962). Personal communication.

GUILLAUME, J. (1972). Données complémentaires sur les besoins nutritionnels de la reproductrice naine Vedette I.N.R.A.-Jv. 15. Ann. Genet. Sel. anim. 4: 281 .

GUillaUME, J. (1973). Effets du gène de nanisme lié au sexe dw sur le métabolisme énergétique de la poule. 6rh Symposium on Energy Metabolism, Stuttgart, publ. E.A.A.P. no. 14 .

GUILlAUME, J. (1976). The dwarfing gene dw: its effects on anatomy, physiology, nutrition, management. Its application in poultry industry. World's Poultry Science Journal 32:285.

HAAS, W. P., KOTELAS, R. M., STEPHENS, J. F., JAAP, R. G. (1975), Effect of the Jwarfing gene (dw) on susceptibility to selected cocidial and bacterial infections. Poultry Science 54: 1770 (abstr.).

HARTMANN. W. (1978). Untersuchungen zur Wirtschaftlichen Bedeutung der Geschlechtsgebundenen verzwergungs faktors "dw" bein Mastgeflügel. I. Ein fluss des Faktors "dw" auf die Leistungen von Mastelterhennen. Archiv. fur Geflügelk. 42: 29

HAZEN, K. R., WALDROUP, P. W. (1971). Caloric intake restriction of dwarf broiler breeders. Poultry Science 50: 1585 (abstr.)

HORST, P., PETERSEN, J. (1978). Der Effekt das dwarf-genes auf das Akklimatizationsvermögen von Legehennen an hole temperaturen. Proceedings I6th World's Poultry Congress I: 247.

HORST, P., PETERSEN, J. (1979). Der Effekt des dwarf-genes auf das Akklimatizationsvermogen von Legehennen an hole Umwelt-temperaturen. Archiv für Geflügelk, 43: 242

HUTT, F. B. (1959). Sex-linked dwarfism in the fowl. Jounral of Heredity 50: 209.

JAAP, R. G. (1968a). Reproductive idiosyncrasies of the broiler pullet. 3rd European Poultry Conference, Jerusalem 74.

JAAP, R. G. (1968b). Sex-linked dwarfism and broiler production. Pouttry Science $47: 1684$ (abstr.)

JAAP, R. G. (1969). Large broilers from smaller hens. World's Poullry Science Journal 25: 140.

JAAP, R. G., MOHAMMADIAN, M. (1969). Sex-linked dwarfism and egg production of broiler dams. Poultry Science 48: 344.

JAAP, R. G., MUIR, F. V. (1968). Erratic ovipositions and egg defects in broiler pullets. Poultry Science 47:417.

KHAN, A. G. (1973). Selection response and the per formance of crossbred progeny from normal and dwarf broiler breeder dams. Dissertation Abstracts 53: 5684 .

KHAN, A. G., JAAP, R. G. (1974). Selection response and the performance of crossbred progeny from normal and dwarf broiler breeder dams. Isth World's Congress of Genetics applied to animal production, Madrid, III, 427

KHAN, A. G., JAAP, R. G., KANOUN, A. K. (1975). Body growth response to selection and erossbreeding in dwarf and normal broiler -type chickens. Poultry Science 54: 1239.

KLINGENSMITH, P. M., STEPHENS, J. M., DONAHOE, J. P. (1982). The effect of the sex-linked dwarfing gene, dw, on the immune response of broiler breeder chicks. Poultry Science 61: 1492 (abstr.).

KUIT, A. R., VAN MIDDELKOOP, J. H. (1972). The possibility to avoid irregular ovipositions by means of sex-linked dwarfism Ann. genet. Sel. Anim. 4:225.

LARBIER, M. BLUM, J. C. (1975). Influence de la méthionine, ajoutée au régime alimentaire de la poule pondeuse ou injectée dans l'oeuf, sur le développement embryonnaire et post-natal du poussin. C.R. Acad. Sci. Paris Série D., $280: 2133$.

LECLERCQ, B., BLUM, J. C. (1972). Effets de la restriction alimentaire pendant la période de croissance sur les performances des reproductrices naines. Ann. Genet. Sel. anim. 4: 259

LECLERCQ, B., BLUM, J. C. (1973). Etude de l'alimentation de la poulette: Interaction entre mode de restriction, gène de nanisme et type de pondeuse. Journées de recherches avicoles et cunicoles. Publ. ITAVI. p. 211

LECLERCQ, B., BLUM, J. C. (1975). Restricted feeding of growing pullets: Interaction between the method of restriction and the dwarfism gene (dw). Archiv. für Geflügelk. 39: 153.

LECLERCQ, B., GUILLAUME, J., BLUM, J. C. (1972). Données sur les besoins alimentaires de la reproductrice naine Vedette INRA (dw) durant la période de croissance et de ponte. II. Période de ponte. Proceedings XIVth World's Poultry Congress, Madrid, 790 .

MARKS, H. L. (1981). The sex-linked dwarf gene as expressed in two meat-type control lines of chickens. Poultry Science 60: 1127.

MARKS, H. L. (1983). Selection for body weight at eight weeks of age in dwarf and normal meat-type chickens originating from a common control population background. Poultry Science 62: 227.

MARSTELLER, F. A., GROSS, W, B., SIEGEL, B. (1980). Antibody production and E. coli resistance in socially stable flocks of dwarf and non-dwarf chicks. Poultry Science 59: 1947.

MAULDIN, J. M., SIEGEL, P. B., GROSS, W. B. (1978). Dwarfism in diverse genetic backgrounds. 2. Behaviour and disease resistance. Pouliry Science 57: 1488

MAULDIN, J. M., MARSTELLER, F. A., GROSS, W. B., SIEGEL, P. B. (1981). The relationship between the dwarfing gene and E. coli infection in two populations of chickens. Journal of Heredity $72: 125$.

MERAT, P., BORDAS, A., LEFEBVRE, J. (1974). Effets associés aux gènes dw (nanisme) et Na ("cou nu") chez la poule sur la production d'oeufs et la consommation alimentaire à deux temperatures. Ann. Genet. Sel. anim. 6: 331 .

MERAT, P., RICARD, F. H. (1974). Etude d'un gène de nanisme lié au sexe chez la poule: importance de l'état d'engraissement et gain de poids chez l'adulte. Ann. Genet. Sel. anim. 6: 211 .

MERRITT, E. S., GOWE, R. S. (1965). Post-embryonic growth in relation to egg-weight. Poultry Science 44: 477.

MEURIER, C., MERAT, P. (1972) Résistance de cerıains génotypes à la maladie de Marek chez la poule. III. Influence possible du gène de nanisme dw. Ann. Genet. Sel. Anim. 4:41.

MOHAMMADIAN, M. (1969). Physiological effects of the sex-linked dwarfing gene, dw, in broilers. Poultry Science 48: 1845 (abstr.).

MOHAMMADIAN, M. (1970). Phenotypic variation attributable to dwarf allele, dw, in broiler chicken. Poultry Science 49: 4417 (abstr.).

MOHAMMADIAN, M., JAAP, R. G. (1972). Effect of the sex-linked dwarfing gene on body growth of chickens. Poultry Science S1: 1701

MORRIS, R. H., HESSELS, D. F., BISHOP, R. J. (1968). The relationship between hatching egg weight and subsequent performance of broilers chicks. British Poultry Science 9: 305.

PERSIL, M. (1972). Aspect économique de l'utilisation de la reproductrice Vedette INRA JV15 dans la production du poulet de chair. These Vet. Lyon.

PETITJEAN, M. J., DE REVIERS, M., (1973). Effets du gène de nanisme dw sur la maturite sexuelle des coqs. Proceedings 4th European Poultry Conference, London 569.

POLKINGHORNE, R. W. (1973). The dwarf gene dw in poultry and its application to the Australian Poultry industry. Journat Australian Institute of Agricultural Science 39: 41

POLKINGHORNE, R. W., HARVEY, W. R. (1978). Genetic correlation between genes for body weight in dwarf and normal broilers. Poultry Science 57: 1181 (abstr.). 
POWELL, J.C., BOWNAN, J.C. (1964). An estimate of maternal ef fects in embryos growth characteristics and its ef fects upon comparative tests of chicken varieties. British Poultry Science 5: 121

PROD'HOMME, J., MERAT, P. (1969). Etude d'un gène de nanisme liè au sexe chez la poule. III. Consommation alimentaire et production suivant la teneur en calcium de la ration. Ann. Genet Sel. anim. 1: 135.

PROUDFOOT, F. G., HULAN, H. W., MCRAE, K. B. (1982). Effect of hatching egg size from semi-dwarf and normal maternal meat parent genotypes on the performances of broiler chickens. Poulery Science 61: 655.

RAPP, K. G. (1970). Die wistschaftlichkeit einer Zwerg-mutante der weissen-Leghorn in der Linienvund HydridenZucht. Thesis, Göttingen Universität.

DE REVIERS, M., PETITJEAN, M. J. (1973). Effets du gène de nanisme dw sur la production de spermatozoides chez le coq en croissance. Ann. Genet. Sel. anim. 5: 313.

REDDY, P. R. K., GROSS, W. B., VAN KREY, H. P., SIEGEL, P. B. (1975). Blood parameters of dwarf and normal pullets from growth selected lines before and after E. Coli challenge. Poultry Science 54: 674

REDDY, P. R. K., SIEGEL, B. (1977). Selection for body weight at 8 weeks of age. 14. Effects of the sex-linked dwarf gene. Poultry Science 56: 1004 .

REDDY, P. R. K., UDALE, R. W., SIEGEL, P. B. (1974). Growth and reproduction of dwart and normal sibs in diverse genetic backgrounds, Poultry Science 53; $[970$ (abstr.).

RICARD, F. H. (1972). Croissance et caractéristiques de carcasses de poulets issus de mères normales ou naines (dw). Ann. Genet. Sel anim. 4: 173 .

RICARD, F. H. (1976). Bases scientifiques de l'utilisation du gène de nanisme $d w$ dans la production du poulet de chair. Proceedings $5 t h$ European Pouttry Conference Malta. p. 263

RICARD, F. H., COCHEZ, L. P. (1972). Le gène de nanisme dw et les performances des poules dans une souche de type femelle chair. Ann. Genet. Sel. anim. 4:297.

RICARD, F. H., COCHEZ. L, P. (1973). Influence du gène de nanisme, dw, sur la variabilité génétique du poids vif et des mesures de conformation chez le poulet. Proceedings 4 th European Poultry Conference, London, 551

RICARD, F. H., CONAN, L. (1974). Performance zootechnique de poulets normaux fils de mères normales ou naines. Proceedings I5th World's Poultry Congress, 24

SHER WOOD, D H. (1971). Comparison of madget meat-type breeder chickens with a normal strain. Poultry Science 50: 1630 (abstr.)

SILBER, J., MERAT, P. (1974a). Etude génétique de la ponte d'oeufs mous chez la poule. Proceedings 15 th World's Poultry Congress 491 .

SILBER, J., MERAT, P. (1974b). Etude génétique sur les oeufs cassés en batterie de ponte. Proceedings 15 th World's Poultry Congress, 266.

STEPHENS, J. F., DREYFUSS, M. S. (1978). Sex-linked dwarfism and response to two Newcastle disease vaccines. Poultry Science 57: 823.

STEWART, P. A., WASHBURN, K. W. (1982). The effect of the dw gene on growth and metabolism in a broiler strain. Poultry Science 61: 1397 (abstr.).

STRAIN, J. H., PILOSKl, A. P. (1975). Performance of dwarf broiler breeders in laying cages and floor pens and of normal breeders in floor pens. Canadian Journal of Animal Science 55; 741

IIMMONS, D. (1971). Mini-hens cut broiler chick costs. Poultry International 10: (Oct. 1971) 10

VAN MIDDELKOOP, J. H. (1973). Influence of the dwarfing gene on yolk production and its consequences for normal egg laying of White Plymouth Rock pullets. Archiv. fur. Geflugelk. 37: 192

VAN MIDDLEKOOP, J. H., ZEGWAARD, A. (1973). (Dwarf broiler mothers and hatching egg weight). Spelderholt Meded 203: 1.

WALDROUP, P. W., HAZEN, K. R. (1975). Energy needs of dwarf (dw) broiler breeder hens. Poultry Science 54: 1931.

WALDROUP, P. W., HAZEN, K. R. (1976). A comparison of the daily energy needs of the normal and dwarf broiler breeder hen. Poultry Science 5s: 1383 .

WEAVER, W. D., Jr. (1974). Mini-breeders pay if raising squab broilers. Broiler Industry 37: 23.

WHITING, R. S., PESTI, G. M. (1982). Broiler performance and hatching egg weight to marketing weight relationships of progeny from regular and dwarf broiler breeders. Poultry Science 61: 140 (abstr.).

YAMADA, Y., WATANABE, K., EBISAWA, S, FUTAMURA, K. (1972). (Effect of the sex-linked dwarf gene on performance of broiler dams. J Japanese Poultry Science 9: 286. 